\title{
Sikap Ilmiah dan Kreativitas Produk pada Isu Lingkungan melalui Pembelajaran Berbasiskan Proyek
}

\author{
YUSTINA, SUWONDO \\ Laboratorium Pendidikan Biologi Jurusan Pendidikan Matematika dan Ilmu Pengetahuan Alam \\ Fakultas Keguruan Dan Ilmu Pendidikan Universitas Riau \\ *email: hj_yustin @ yahoo.com
}

Manuscript received: 23 Mei 2015 Revision accepted: 30 Juli 2015

\begin{abstract}
The purpose of this research was to got the information about student's scientific attitude and creativity of product and correlation both of it in enviromental issues through project based learning. This research was conducted from January to June 2015. Sample in this research are 34 students of 2014 grade in FKIP Biologi UR used parameters are (1) scientific attitude with 4 indicators (curiosity, cooperative, carefulness and discipline); (2) creativity of product. Observation instrument managed by reseacher and the realibility values based Alfa Cronbach is $0.70-0.87$. The creativity was scored through product (report) by using portofolio instrument, with descriptors are : Initiative (collecting information), inovation (environmental issues that are happening), variation of idea (way of display data), and suitable idea and their solution. The data analyzed is using SPSS. Descriptive statistic are percent, mean, standard deviation and inference statistic (Multiple regretion). Mean values shows us that student's scientific attitude is 79,99 (good), and the creativity of product is 80,10 (good). Positive correlation among curiosity, cooperation, carefulness and discipline give contribution as $68 \%$ to determine the creativity of product. Separately, each aspect of student's scientific attitude give contribution for creativity of product are : curiosity $(60 \%)$, carefulness $(57 \%)$, discipline $(48 \%)$ and cooperative $(47 \%)$. The conclusion is student's scientific attitude and creativity of product is in good category, It mean was there are correlation between student's scientific attitude and the creativity of product in environmental issues through project based learning in FKIP Biologi UR.
\end{abstract}

Keywords: Student's Scientific Attitude, Creativity, Environmental Course, Project Based Learning

\section{LATAR BELAKANG}

Ilmu Pengetahuan Lingkungan (IPL) merupakan salah satu mata kuliah pada semua jurusan di FKIP Universitas Riau yang diberikan pada mahasiswa semester II dengan bobot 3 SKS. Di program studi pendidikan biologi IPL termasuk kedalam Mata Kuliah Keahlian Berkarya (MKKB). Tujuan mata kuliah ilmu pengetahuan lingkungan adalah agar mahasiswa mengetahui pentingnya menjaga lingkungan.

Materi perkuliahan yag disajikan didalam mata kuliah IPL berupa masalah yang terjadi di lingkungan, perubahan yang terjadi dan hubungan manusia dengan lingkungan. Terdapat beberapa contoh materi yang di pelajari dalam mata kuliah IPL, diantaranya adalah permasalahan lingkungan lokal dan global. Salah satu issu lokal dan nasional tentang lingkungan adalah visi Indonesia sehat.

Menurut ketentuan DEPKES (2006) tentang Visi Indonesia sehat pada tahun 2010 dan visi Riau sehat pada tahun 2008 yaitu pada tahun tersebut terwujud masyarakat dengan perilaku lingkungan hidup bersih dan sehat (PLHBS). Ditinjau dari tahun pencanagan, berarti pada saat ini dalam masyarakat PLHBS sudah terwujud. Namun masih dijumpai masyarakat, khususnya mahasiswa yang tidak mengimplementasikan PLHBS dalam kehidupan kesehariannya, seperti pemeliharaan kebersihan lingkungan pondokan dan kampus.

Mahasiswa sebagai masyarakat ilmiah seharusnya sudah mencerminkan sikap ilmiah terkait PLHBS dengan permasyalahan lingkungan hidup. Sebagai calon guru yang nantinya akan menjadi model dan teladan untuk menerapkan kepada peserta didik tentang tujuan pembelajaran lingkungan serta pentingnya menjaga lingkungan. Kualitas pembelajaran lingkungan menuntut kreativitas guru, antara-lain dengan melakukan inovasi pembelajaran lingkungan, sehingga dapat meningkatkan penguasaan konsep, sikap, minat dan partisipasi siswa dalam mengelola lingkungan (Yustina, 2007).

Inovasi pembelajarn dapat melalui pembaharuan strategi, metode, pendekatan, model pembelajaran serta menerapkan berbagai bentuk aspek penilaian. Sejalan dengan diimplementasikannya kurikulum 2013 (KUTILAS), maka diterapkan 3 ranah penilaian dalam pembelajaran lingkungan. Salah satu adalah penilaian sikap, seperti sikap ilmiah mahasiswa.

Inovasi model pembelajaran dalam KUTILAS, seperti pembelajaran berbasis proyek $(\mathrm{Pj}-\mathrm{BL})$ diduga dapat membantu siswa mengeksploitasi sikap ilmiah. Pembelajaran Berbasis Proyek merupakan model pembelajaran yang menggunakan masalah sebagai langkah awal dalam mengumpulkan pengetahuan berdasarkan pengalamannya. Pembelajaran Berbasis Proyek dirancang untuk digunakan pada permasalahan kompleks yang diperlukan peserta didik dalam memahaminya (Kementerian Pendidikan dan Kebudayaan, 2013).

Model Pj-BL memiliki ciri spesifik yaitu model pembelajaran yang memupuk pemikiran kreatif dan menghasilkan produk. Produk dapat berupa laporan, artikel, kliping maupun produk pembelajaran lainnya. Hasil 
tugas proyek pada kegiatan ini adalah kreativitas produk berupa laporan/artikel ilmiah. Gou dan Yang (2012) bahwa menyatakan bahwa kelebihan pembelajaran berbasis proyek adalah menuntut peserta didik berperan aktif, mampu mengembangkan kemandirian, memiliki rasa ingin tahu yang besar, kedisiplinan, bertanggung jawab, inisiatif, kritis dan inovatif dalam mencapai tujuan pembelajaran. Maka dari itu, mahasiswa dituntut mengembangkan sikap ilmiah agar menghasil kreativitas produk yang lebih baik.

Dari latar belakang di atas, peneliti ingin mengetahui lebih lanjut bagaimana hubungan sikap ilmiah mahasiswa dan kreativitas produk, serta bagaimana hubungan antara sikap ilmiah dengan kreativitas produk dalam pembelajaran lingkungan berbasiskan proyek di Program Studi Pendidikan Biologi FKIP Universitas Riau, agar dapat dijadikan informasi dan sebagai tolak ukur untuk menentukan remedial dan pengembangan rancangan pembelajaran pada tahun berikutnya.

\section{METODE}

Penelitian dilaksanakan di Program Studi Pendidikan Biologi FKIP Universitas Riau pada semester genap tahun akademis 2014/2015. Pada bulan Januari sampai dengan Juni 2015. Penelitian ini merupakan penelitian deskriptif yaitu memberikan gambaran dari penafsiran data tentang sikap ilmiah dan kreativitas produk mahasiswa dalam pembelajaran ilmu pengetahuan lingkungan.

Populasi dalam penelitian ini adalah mahasiswa program studi pendidikan biologi FKIP Universitas Riau yang mengambil mata kuliah Ilmu Pengetahuan Lingkungan (IPL) pada semester genap TA 2012/2013. Sampel dalam penelitian ini adalah mahasiswa angkatan 2014 di kelas A dengan jumlah 34 orang mahasiswa (23 orang perempuan dan 11 orang laki-laki). Sampel ditentukan dengan teknik Purposive sampling (bertujuan) dengan mempertimbangankan proses pembelajaran yang dilakukan pada mata kuliah IPL. Parameter dalam penelitian ini adalah sikap ilmiah mahasiswa yang mencakup 4 indikator, di antaranya:(1) Rasa Ingin Tahu; (2) Kerjasama; (3) Teliti; dan (4) Disiplin.

Instrumen penelitian terdiri atas 2 yaitu, Lembar Observasi (LO) dan lembar portpolio untuk menilai kreativitas produk (laporan) terdiri dari: inisiatif (mengumpulkan informasi), inovasi(isu lingkungan kekinian), variasi ide (tampilan data), dan kesesuaian idea dengan solusi. Pengambilan data dengan mengunakan lembar observasi oleh 3 orang observer. Data diambil sebanyak 4 kali pertemuan pada saat proses pembelajaran saat tugas proyek berlangsung. Pengamatan yang dilakukan, berpedoman pada deskriptor yang telah ada untuk masing-masing indikator sikap ilmiah

Data sikap ilmiah yang terkumpul terlebih dahulu dikonversi kesatuan perseratus, disajikan mengunakan tabel. Interval dan kategori sikap ilmiah mahasiswa yang digunakan adalah > 86 (kategori sangat baik ),75-86 (kategori baik), 65- <75 (kategori cukup), < 65 (kategori kurang) (Modifikasi Purwanto 2008). Penganalisaan data menggunakan program SPSS. Statistik deskriptif yaitu persen, mean, standar deviasi dan statistik inferensi yaitu Regresi Berganda digunakan dalam penelitian ini.

\section{HASIL DAN PEMBAHASAN}

\section{Profil Hasil Observasi (Sikap Ilmiah) dan Penilaian Portpolio Berupa Kreativitas Produk (Laporan) Tugas Proyek Pembelajaran IPL}

Berdasarkan data yang telah dianalisis, didapatkan informasi mengenai sikap ilmiah mahasiswa dan kreativitas produk disajikan pada Tabel 1.

Tabel 1 Skor Sikap ilmiah dan Kreativitas produk dalam Pembelajaran IPL Berbasiskan Proyek

\begin{tabular}{lcccccc}
\hline \multicolumn{1}{c}{ Indikator } & $\mathrm{N}$ & $\begin{array}{c}\text { Skor } \\
\text { Min }\end{array}$ & $\begin{array}{c}\text { Skor } \\
\text { Maks. }\end{array}$ & $\begin{array}{c}\text { Simpanga } \\
\mathrm{n} \\
\text { Baku }\end{array}$ & $\begin{array}{c}\text { Skor } \\
\text { Rerata }\end{array}$ & Ktg \\
\hline $\begin{array}{l}\text { Rasa ingin } \\
\text { tahu }\end{array}$ & 34 & 46 & 68 & 4.67 & 74,85 & $\mathrm{C}$ \\
Kerjasama & 34 & 60 & 81 & 3.05 & 81,53 & $\mathrm{~B}$ \\
Teliti & 34 & 55 & 83 & 5.24 & 76,39 & $\mathrm{~B}$ \\
Disiplin & 34 & 65 & 87 & 3.45 & 87,20 & $\mathrm{SB}$ \\
\hline \multicolumn{2}{l}{ Skor Rerata Sikap Ilmiah } & & & 79.99 & $\mathrm{~B}$ \\
\hline Kreativitas & 34 & 68 & 90 & 8.50 & 80,10 & $\mathrm{~B}$
\end{tabular}

Ket.: Sangat Baik (SB), Baik (B), Cukup (C), Kurang (K)

Berdasarkan data pada tabel 1, dapat dilihat sikap ilmiah mahasiswa pada matakuliah IPL dari hasil observasi 34 orang mahasiswa yang dilakukan sebanyak 4 kali pertemuan. Dari 4 indikator sikap ilmiah, maka diperoleh skor rerata sikap ilmiah mahasiwa sebesar 79.99 dikategorikan baik. Skor rerata terendah dari keempat indikator sikap ilmiah adalah pada skor rasa ingin tahu (68) dikategorikan cukup, skor rerata sikap kerjasana dan teliti masing-masing $(81,53$ dan 76,39$)$ masing-masing dikategorikan baik, dan skor rerata tertinggi adalah disiplin dengan skor $(87,20)$ dikategorikan sangat baik.

Berdasarkan penilaian menggunakan portpolio didapati kreativitas produk berupa laporan ilmiah berkisar antara 68 sampai 90, dengan skor rerata sebesar 80,10 dikategorikan baik.

\section{Hubungan Sikap Ilmiah Rasa Ingin Tahu, Kerjasama, Teliti, Disiplin Dengan Kreativitas Produk Pembelajarn IPL}

Hasil pengujian hipotesa menunjukkan hubungan positif antara rasa ingin tahu tentang pengetahuan lingkungan dengan kreativitas dengan koefisien korelasi sebesar 0,59 dan signifikan pada alpha 0,05. Selanjutnya apabila variabel lain dikontrol ditemukan nilai korelasi parsial sebesar $60 \%$ dan signifikan pada alpha $=0,05$. Hasil analisis regresi menunjukkan indeks determinasi sebesar 0,48 . Hal ini menunjukkan, bahwa 48 persen variasi pemikiran kreatif dijelaskan variabel sikap rasa ingin tahu melalui persamaan regresi $\mathrm{Y}=41,5+0,70 \mathrm{X}_{1}$. Pengujian 
linearitas diperoleh $\mathrm{F}_{\mathrm{h}}=1,21<\mathrm{F}_{\mathrm{t}}=1,86$, yang berarti linear dan signifikan $\left(\mathrm{Fh}=127>\mathrm{F}_{\mathrm{t}}=3,9\right)$. Dengan persamaan tersebut dapat diinterprestasikan bahwa apabila variabel sikap rasa ingin tahu dan kreativitas produk IPL dengan menggunakan instrumen yang dikembangkan dalam penelitian ini maka setiap perubahan sikap rasa ingin tahu sebesar satu unit dapat diestimasikan pemikiran kreativitas produk meningkat sebesar 0,70 unit pada arah yang sama dengan kostanta 41,5 .

Hasil pengujian hipotesa menunjukkan hubungan positif antara sikap kerjasama dalam mengerjakan tugas proyek dengan kreativitas dengan koefisien korelasi sebesar 0,56 dan signifikan pada alpha 0,05. Selanjutnya apabila variabel lain dikontrol ditemukan nilai korelasi parsial sebesar $47 \%$ dan signifikan pada alpha $=0,05$. Hasil analisis regresi menunjukkan indeks determinasi sebesar 0,37 . Hal ini menunjukkan, bahwa 37 persen variasi kreativitas dijelaskan variabel sikap kerjasama dalam mengerjakan tugas proyek melalui persamaan regresi $\mathrm{Y}=$ $30,6+1,78 \mathrm{X}_{2}$. Pengujian linearitas diperoleh $\mathrm{F}_{\mathrm{h}}=1,21<$ $F_{t}=1,76$, yang berarti linear dan signifikan $\left(F h=127>F_{t}\right.$ $=2,9$ ). Dengan persamaan tersebut dapat diinterprestasikan bahwa apabila variabel kerjasama dan kreativitas produk IPL dengan menggunakan instrumen yang dikembangkan dalam penelitian ini maka setiap perubahan kerjasama sebesar satu unit dapat diestimasikan kreativitas produk meningkat sebesar 1,78 unit pada arah yang sama dengan kostanta $-30,6$.

Hasil pengujian hipotesa menunjukkan hubungan positif antara sikap teliti dengan kreativitas dengan koefisien korelasi sebesar 0,53 dan signifikan pada alpha 0,05 . Selanjutnya apabila variabel lain dikontrol ditemukan nilai korelasi parsial sebesar $57 \%$ dan signifikan pada alpha $=0,05$. Hasil analisis regresi menunjukkan indeks determinasi sebesar 0,43. Hal ini menunjukkan, bahwa 43 persen variasi kreativitas produk dijelaskan variabel sikap teliti melalui persamaan regresi $\mathrm{Y}=42,5+0,78 \mathrm{X}_{3}$. Pengujian linearitas diperoleh $\mathrm{F}_{\mathrm{h}}=1,28<\mathrm{F}_{\mathrm{t}}=1,86$, yang berarti linear dan signifikan $\left(F h=67,4>F_{t}=3,94\right)$. Dengan persamaan tersebut dapat diinterprestasikan bahwa apabila variabel sikap teliti dan kreativitas produk 1 IPL dengan menggunakan instrumen yang dikembangkan dalam penelitian ini maka setiap perubahan sikap teliti sebesar satu unit dapat diestimasikan kreativitas produk meningkat sebesar 0,78 unit pada arah yang sama dengan kostanta 42,5 .

Hasil pengujian hipotesa menunjukkan hubungan positif antara sikap disiplin dengan kreativitas dengan koefisien korelasi sebesar 0,50 dan signifikan pada alpha 0,05 . Selanjutnya apabila variabel lain dikontrol ditemukan nilai korelasi parsial sebesar $48 \%$ dan signifikan pada alpha $=0,05$. Hasil analisis regresi menunjukkan indeks determinasi sebesar 0,37. Hal ini menunjukkan, bahwa 37 persen variasi kreativitas produk dijelaskan variabel sikap disiplin melalui persamaan regresi $\mathrm{Y}=26,6+0,68 \mathrm{X}_{4}$. Pengujian linearitas diperoleh $F_{h}=1,28<F_{t}=1,86$, yang berarti linear dan signifikan $\left(F h=76,3>F_{t}=3,94\right)$. Dengan persamaan tersebut dapat diinterprestasikan bahwa apabila variabel disiplin dan kreativitas produk IPL dengan menggunakan instrumen yang dikembangkan dalam penelitian ini maka setiap perubahan sikap disiplin sebesar satu unit dapat diestimasikan kreativitas meningkat sebesar 0,68 unit pada arah yang sama dengan kostanta 26,6.

Hasil pengujian hipotesis menunjukkan hubungan positif secara bersama-sama antara sikap ingin tahu, kerjasama, teliti dan disiplin dengan kreativitas produk dalam hasil belajar IPL dengan koefisien korelasi (R) sebesar 0,63 dan signifikan pada alpha $=0,05\left(\mathrm{~F}_{\mathrm{h}}=79,03\right.$ $>3,94$ ) dengan indeks determinasi 0,68 melalui persamaan regresi $Y=-34,42+0,58 X_{1}+0,52 X_{2}+0,57 X_{3}+0,38$ $\mathrm{X}_{4}$. Secara bersama-sama keempat variabel bebas memberikan kontribusi sebesar $68 \%$ dalam menentukan pemikiran kreatif pada hasil belajar IPL berbasiskan proyek. Dengan demikian kreativitas produk IPL, sikap rasa ingin tahu dan sikap teliti dalam melaporkan kegiatan berbasis proyek dalam bentuk artikel ilmiah merupakan variabel cukup dominan dalam menentukan kreativitas produk dalam bentuk laporan/artikel ilmiah IPL.

Ditinjau dari peringkat kekuatan hubungan masingmasing variabel dengan mengontrol variabel bebasnya, dapat disimpulkan peringkat pertama adalah variabel sikap rasa ingin tahu $\left(\mathrm{X}_{1}\right)$ dengan $\mathrm{r}_{\mathrm{y} 1234}=0,60$, sedangkan peringkat kedua adalah variabel sikap teliti dalam mengerjakan kerja proyek $\left(\mathrm{X}_{3}\right)$ dengan $\mathrm{r}_{\mathrm{y} 3124}=0,57$. Peringkat akhir secara berurut adalah variabel sikap disiplin $\left(\mathrm{X}_{4}\right)$ dengan $\mathrm{r}_{\mathrm{y} 4123}=0,48$ dan variabel sikap kerjasama $\left(\mathrm{X}_{2}\right)$ dengan $\mathrm{r}_{\mathrm{y} 2134}=0,47$.

\section{Pembahasan}

Indikator rasa ingin tahu secara keseluruhan menunjukan kategori cukup (74,85), karena selama kegiatan pembelajaran masih ada mahasiswa yang kurang memperhatikan dan merespon penjelasan dari dosen, seperti tidak ada keinginan mahasiswa mencatat penjelasan yang dianggap penting, tampak hanya beberapa orang mahasiswa yang berani mengajukan pertanyaan terkait dengan topik materi pembelajaran, istilah-istilah yang belum mereka ketahui, dan hanya mahasiswa yang aktif saja yang mau mencari informasi tambahan dari sumber bacaan lain sebagai pendukung topik materi.

Sebaliknya selama proses pembelajaran berlangsung, ada sebahagian mahasiswa terlihat sangat antusias dan serius dalam proses pembelajaran, rasa ingin tahu peserta terlihat mulai dari persiapan proyek sampai proses pelaksanaan pembelajaran. Hal ini terlihat saat peserta menyusun rancangan kerja, saat berdiskusi peserta selain membaca petunjuk kerja secara cermat, juga menggunakan berbagai sumber informasi yang terkait dengan topik yang sedang dipelajari. adanya rasa ingin tahu yang tinggi dapat sebagai pemicu semangat motivasi belajar yang baik.

Sikap ilmiah adalah keterbukaan pikiran: keinginan akan keakuratan pengetahuan, terstruktur dan sistematis. memperlihatkan solusi dan harapan dari masalah selama kita terus menggunakan pengetahuan (Singh, 1988 dan Yustina at all, 2010). Sikap ilmiah didefinisikan sebagai kesatuan emosional dan ide tentang pengetahuan, metode ilmiah dan hubungan secara langsung maupun tidak 
langsung terhadap perilaku dalam pendidikan ilmiah (Uday, 2014). Selanjutnya Jonathan, O. (2013) menyatakan bahwa sikap ilmiah sangat berguna untuk mengidentifikasi masalah, dengan kata lain sikap ilmiah adalah bagaimana suatu masalah dapat diperbaiki.

Dari sikap ilmiah yang diamati dalam pelaksanaan perkuliahan tiap pertemuannya memiliki persentase yang berbeda-beda. Perbedaan tersebut disebabkan beberapa hal baik berkaitan dengan materi yang dipelajari, waktu pelaksanaan pembelajaran maupun dari motivasi belajar mahasiswa yang terkadang menurun. Menurut Suryabrata (2004), bahwa dengan adanya sifat ingin tahu dan ingin menyelidiki dunia luas merupakan salah satu hal yang mendorong seseorang untuk belajar. Selanjutnya keingintahuan terhadap lingkungan secara kontekstual akan dapat meningkatkan motivasi belajar (Yustina dan Febrita, 2013). Hal ini berarti bahwa perubahan atau perbedaan sikap ingin tahu pada peserta didik dapat disebabkan motivasi belajar.

Indikator kerjasama secara keseluruhan menunjukan kategori baik(81,53\%), hal ini tampak dari mahasiswa yang saling bekerjasama dan berbagi tugas dalam mengerjakan tugas, selain itu mahasiswa juga tampak berbagi informasi dengan teman dalam satu kelompoknya. Baiknya sikap kerjasama juga dikarenakan mahasiswa telah terbiasa dikondisikan untuk bekerjasama dalam kelompok, sehingga setiap mahasiswa memiliki kesempatan untuk memberikan kontribusi pemikirannya dalam menyelesaikan semua tugas yang diberikan dengan tepat waktu. Hal tersebut sesuai dengan pendapat Trianto (2010), bahwa kerjasama akan terlihat apabila mahasiswa terlibat didalam kelompok. Slavin (2009) menyatakan bahwa apabila anggota team sangat antusias untuk mencapai satu tujuan, mereka akan saling membantu, berkontribusi, bertanggung jawab dan mendukung evaluasi kinerja satu sama lain untuk mencapai tujuan tersebut. Keunggulan pembelajaran mengunakan model $\mathrm{Pj}-\mathrm{BL}$ dapat membantu kemajuan pada mahasiswa kearah pengembangan sikap, nilai, dan tingkah laku yang memungkinkan mahasiswa dapat berpartisipasi dalam satu tujuan yaitu sama-sama untuk membagi ide, saran, saling menghargai pendapat orang lain, saling mengoreksi kesalahan dan saling membantu satu sama lain (Loveless et al., 2006 ).

Indikator teliti secara keseluruhan menunjukan kategori baik dengan persentase (76,36\%). Baiknya sikap teliti yang ditunjukan mahasiswa, tampak dari pengamatan, dengan sangat serius dan teliti dalam mengerjakan sistematika penulisan artikel, mengutip dan merujuk artikel yang bersesuaian, konsistensi dalam penulisan dan runtut dalam mengemukakan pendapat serta terlihat pada hasil kerja mahasiswa, yang umumnya rapi dan sesuai dengan intruksi dosen. Sudjana (2004), menyatakan dosen harus menumbulkan dan memperhatikan aspek psikologi mahasiswa, seperti mengemukankan pendapatnya dan berpartisipasi dalam proses pembelajaran sehingga mahasiswa lebih teliti dalam mengerjakan tugas yang diberikan.
Indikator disiplin secara keseluruhan menunjukan kategori baik sekali dengan persentase $(87,82 \%)$. Sikap disiplin ini merupakan nilai indikator tertinggi dibandingkan dengan keseluruhan indikator pengamatan, tingginya sikap disiplin yang dimiliki mahasiswa terlihat dari tepat waktunya mahasiswa dalam mengerjakan dan mengumpulkan tugas yang diberikan dosen, serta tepat waktu dalam melaksanakan perkuliahan. Selain itu terlihat pada pengamatan, pada saat diskusi kelompok tidak terlihat mahasiswa yang meninggalkan kelompok selama pelaksanaan pembelajaran untuk bergabung dengan kelompok lain dan bermain main dalam mengerjakan tugas.

Usman (2008), menyatakan dalam kegiatan belajar mengajar seseorang perlu dilatih untuk disiplin karena kegiatan akan berjalan dengan baik sekali bila dilakukan secara bersama-sama dengan prinsip sosial. Tumbuhnya sikap kedisiplinan bukan merupakan peristiwa yang terjadi seketika. Kedisiplinan pada diri seseorang tidak dapat tumbuh tanpa adanya campur tangan pendidik yang dilakukan tahap demi tahap.

Hasil penelitian didapat bahwa sikap ilmiah dan kreativitas produk masing-masing dikategorikan baik, selanjutnya uji regresi membuktikan adanya hubunngan positif sikap ilmiah dengan kreativitas produk. Sikap ilmiah yang dominan menentukan kreativitas produk pada penelitian ini adalah sikap ingin tahu dan sikap teliti.

Hal tersebut sesuai dengan pendapat Slavin (2009), motivasi yang diberikan dapat mempengaruhi sikap ilmiah mahasiswa dan karakteristik kepribadian mahasiswa. Dengan tingginya sikap ilmiah mahasiswa dengan kategori baik diharapkan dapat meningkatkan motivasi belajar dan hasil belajar mahasiswa pada matakuliah IPL. Hal ini sejalan dengan hasil penelitian Yustina \& Febrita (2013), bahwa peningkatan motivasi belajar lingkungan melalui kontekstual akan meningkatkan hasil belajar.

Usman (2008) yang mengatakan baik buruknya hasil belajar ditentukan kegiatan atau proses pembelajaran itu sendiri. Jika didalam proses pembelajaran digunakan strategi, pendekatan, model, metode dan pembelajaran yang sesuai dengan topik dan kondisi peserta didik, maka hasil belajar juga akan baik.

Cakici dan Turkmen (2013), mengatakan pendekatan ilmu kontekstual memungkinkan untuk mengakomodasi kompetensi peserta didik dalam membangun ide-ide baru diperoleh dari pengalaman awal. Hal ini dapat mendorong kreativitas lebih bervariasi dalam perjalanan pelajaran yang berkaitan dengan mengimplementasikan Pembelajaran Berbasis Proyek.

Pembelajaran berbasis proyek memberikan kesempatan dan inisiatif pada setiap pribadi siswa untuk mengerjakan proyeknya. Ini menyiratkan bahwa secara otomatis dengan menghargai kepribadian peserta, mendukung serta memberikan kesempatan untuk melakukan pemikiran kreatif, sehingga banyak kreativitas dan inovasi yang akan dihasilkan. Fakta ini sejalan dengan pernyataan Loveless et al., (2006), mengatakan bahwa kreativitas ada sebagai sebuah konsep yang kompleks yang berkaitan dengan peran lingkungan, perspektif kognitif dan psikomotor dan 
kreativitas sebagai tindakan kemandirian individu. Membangun pengetahuan pembelajaran adalah unit penting dalam mengembangkan kreativitas dan menciptakan iklim motivasi yang tepat untuk perbaikan hasil belajar siswa.

Selanjutnya Munandar (1999) menegaskan untuk membangkitkan kreativitas, peserta didik perlu diberi kesempatan yang cukup untuk terlibat dalam berbagai program kreativitas dan mengekspresikan diri secara kreatif. Slavola et al (2007) menambahkan bahwa prestasi belajar peserta didik meningkat tergantung pada kreativitas dalam proses pembelajaran. Tujuan kreativitas adalah kemampuan seseorang untuk menciptakan sesuatu yang baru dan itu adalah kombinasi dari data yang dikumpulkan sebelum dan informasi yang diwujudkan dalam sebuah ide atau produk faktual. Hal ini menunjukkan bahwa untuk menghasilkan pemikiran kreatif, berhubungan dengan sikap keingintahuan dan ketelitian dalam mengkoleksi, mengkombinasi informasi dalam mewujutkan produk /ide baru.

\section{KESIMPULAN}

Berdasarkan penelitian yang telah dilakukan, maka dapat disimpulkan: Sikap ilmiah mahasiswa dalam pembelajaran ilmu pengetahuan lingkungan di program studi pendidikan biologi termasuk ke dalam kategori baik, dengan skor rerata sebesar 79.99. Skor terendah dari keempat indikator sikap ilmiah adalah rasa ingin tahu dengan skor (68) dikategorikan cukup, skor sikap kerjasana dan sikap teliti masing-masing (81,53 dan 76,39) masing-masing dikategorikan baik, dan skor tertinggi adalah disiplin sebesar $(87,20)$ dikategorikan sangat baik. Kreativitas produk dari kerja proyek berupa laporan dengan skor rerata 80,10 dikategorikan baik. Adanya hubungan positif secara bersama-sama antara sikap ingin tahu, kerjasama, teliti dan disiplin memberikan kontribusi sebesar $68 \%$ dalam menentukan kreativitas produk. Sikap rasa ingin tahu dan sikap teliti merupakan variabel cukup dominan dalam menentukan kreativitas produk. Peringkat kekuatan hubungan masing-masing sikap ilmiah dalam menetukan kreativitas produk sebagai berikut: peringkat pertama yaitu: sikap rasa ingin tahu $\left(\mathrm{X}_{1}\right)$ sebesar $60 \%$, peringkat kedua adalah sikap teliti $\left(\mathrm{X}_{3}\right)$ sebesar $57 \%$, selanjutnya sikap disiplin $\left(\mathrm{X}_{4}\right)$ sebesar $48 \%$ dan sikap kerjasama $\left(\mathrm{X}_{2}\right)$ sebesar $47 \%$.

Disarankan untuk melakukan penelitian lanjut tentang hubungan sikap ilmiah dengan keteramplilan aplikasi praktis dalam partisipasi aktif mengelola lingkungan.

\section{DAFTAR PUSTAKA}

Cakici, Y. \& Turkmen, N. (2013). An Investigation Of The Effect Of Project-Based Learning Approach On Childrens Achievement And Attitude In Science. The Online Journal Of Science And Technology. 3(2): 9-17

Depkes. (2006). Visi, Misi dan Rencana Strategi Menuju "Indonesia Sehat". Depkes. Jakarta
Gou, S. \& Yang, Y. (2012). Project Based Learning: An Effecive Approach To Link Teacher Professional Development And Students Learning. Journal Of Educational Technology Development And Exchange. 5(2): 41-56

Jonathan, O., (2013). Attitude Towards Science: a Review of the Literature and is Implication. International Journal of Science Education. 25(9): 1049-1079

Kemendikbud. (2013). Permendikbud No. 81A tahun 2013 Tentang Implementasi kurikulum 2013. Kemendikbud. Jakarta

Loveless, A., Burton, J. \& Turvey, K. (2006). Developing conceptual frameworks for creativity, ITC and teacher education. Thinking Skill and Creativity (1) 3-13

Munandar, U,S.C. (1999). Kreativitas \& Keberbakatan Strategi Mewujudkan Potensi Kreatif \& Bakat. Penerbit PT Gramedia Pustaka Utama. Jakarta

Singh, P.N. (1988). Kriya-Biiav-Viciiar-Siiaili Praiinawali. Varanasi. Banaras Hindu University

Slavoha, A., Savvina,J., Cacka, M. \& Volonte, I. (2007). Creative Activity in Conception of Sustainable Development. Education. International Journal of Sustainability in Higher Education. 8(2): 142-154

Slavin,R. E. (2009). Psikologi Pendidikan: Teori dan Praktik Jilid 2. Indeks. Jakarta

Sudjana, N. (2004). Penilaian Hasil Proses Belajar Mengajar. Remaja Rosdakarya. Bandung

Suryabrata,S. (2004). Psikologi Pendidikan. Rajagrafindo Persada. Jakarta

Trianto. (2010). Mendesain Model Pmbelajaran Inovatif Progesif. Kencana. Jakarta

Usman, M.U. (2008). Menjadi Guru Profesional. PT Remaja Rosda Krya. Bandung

Uday, S. (2014). Study of Sciencetific Attitude of B.E.D and B.E.D (Special) Pupil Teachers. Scholarly Research Journal for Interdisciplinary Studies. 2(13): 1815-1822

Yustina. 2007. Kualitas Pembelajaran Lingkungan Hidup Tantangan Menuju Visi Riau Sehat. Prosiding Seminar Internasional Pendidikan Serantau III.Pusat Pengembangan Pendidikan Universitas Riau. Pekanbaru.

Yustina, Kamisah, O. \& Meerah, T.S. (2010). Innovative Approach Inculcating Positive Attitudes and Students Involvement Towards Environment In Biology Classroom. Procedia Social and Behavioral Sciencedirec 2: 3775-3779. Published By Elsevier

Yustina, Elya, F. (2013). Increase Motivation And Knowledge The Environment Through Contextual Model. Asian Social Science. Vol. 9(12): 237-243. 